\title{
招待論文 \\ 流動化処理土の力学特性と今後の課題 MECHANICAL PROPERTY OF LIQUEFIED STABILIZED SOIL AND FUTURE ISSUES
}

\author{
木幡 行宏 1 \\ Yukihiro KOHATA \\ 1 正会員 室蘭工業大学助教授 工学部建設システム工学科 ( $\bar{T} 050-8585$ 室蘭市水元町 27-1) \\ E-mail: kohata@news3.ce.muroran-it.ac.jp
}

Key Words : liquefied stabilized soil, recycling, strength and deformation property, fiber reinforced material, aseismatic performance, ductility

\begin{abstract}
流動化処理土は, 各種構造物の裏込めや地中構造物の埋戻しの際に適切な締固めができない場合に対して建 設発生土を有効に利用寸るために開発されたものであり，締固めが不要で適度な流動性を持たせた泥状の土に 固化材を適量に混合して固化効果を期待寸ることが基本概念である. 近年，社会的に再資源化が大きな時流と なり，都市部で流動化処理土が広く利用されるようになってきた．本論文では，流動化処理土の実績と動向を 概観し, 埋戻し材として用いられる低強度の流動化処理土とシールドトンネルのインバート材に用いられる流 動化処理土の力学特性を概説するとともに, 勒性を改善して耐震性を向上させるために緎維質材料を流動化処 理土に混合した繊維材混合流動化処理土の力学特性を述べる. また, 今後の流動化処理土における課題につい て述べる.
\end{abstract}

\section{1. まえがき}

近年，経済成長の発展に伴い，産業廃棄物の発生量 が増大するとともに質的にも複雑化してきていること から, 環境問題が深刻化し, 各種廃棄物・産業副産物の 排出量を減らすために建設リサイクル法の制定と廃棄 物処理法の改正が行われるなど，社会的にもこれらの 再資源化，リサイクルが大きな時流となっている。こ のような状況の中で, 地盤工学の分野においては多様 な産業副产物に対する様々な有効利用手法が模索され ており, 主として地盤の補強材としてポリエステル繊 維例えば 1) やプラスチック片例えば 2),3) を混合したセメ ント安定処理土の強度・変形特性に関する研究などが 行われており，新たな知見が得られている．また，掘削 残土の有効利用としては, 残土処分地の確保や埋戻し 用山砂の入手など，制約条件が厳しい都市の建設現場 で発生した土砂にセメント等の固化材を混合して再び 埋戻し材として利用する等の流動化処理工法が広く取 り入れられるようになってきている ${ }^{4)}$.しかし, 流動 化処理土には, セメント系安定処理土と同様に強度が 増加するのに伴って脆性的な挙動を示し耐震性能の低 下が生じる恐れがあること, 固化材による強度の増加 は再掘削が必要な箇所への適用を困難にする恐れがあ ること等の指摘がなされている。したがって, 埋戻し 材としての流動化処理土について, 脆性的な力学挙動 を改善し勒性の向上をはかることは重要な課題である.
本論文では，まず，土質材料にセメントを混合して 土質改良を行うという観点から従来のセメント系改良 土と流動化処理土の違いを示し, 流動化処理土の施工 実績と動向について概観する. 次に, 埋戻し材として 用いられる低強度流動化処理土とシールドトンネルの インバート部に用いられる高強度流動化処理土の力学 特性について概説した後, 流動化処理土の而震性向上 を目的に, 流動化処理土に繊維質材料として粉砕した 古紙を混合する方法で作製した繊維材混合流動化処理 土の力学特性について論じる. 最後に, 今後の流動化 処理土における課題について述べる.

\section{2. 流動化処理土の実績と動向}

わが国では昭和 30 年代から, 軟弱な地盤の改良を主 目的に, 石灰安定処理や瀝青安定処理あるいはソイル セメントと呼ばれるセメント安定処理などにより, 高 含水比の軟弱な土を団粒化し良質な地盤材料に改良し て締固めを行うことにより道路や鉄道の路床, 路盤な どに対する浅層地盤改良が行われてきた。また，昭和 40 年代後半からは, 港湾施設や高速道路の建設工事に 伴い, 軟弱な粘性土地盤にセメントを機械的に強制攪 拌混合するセメント系安定処理工法が開発され, 昭和 50 年代に深層混合処理工法が実用化された ${ }^{5)}$. 昭和 60 年代には, セメント系改良土を用いる工法として深層 
混合処理工法が体系的にほぼ完成されたものとなり， 研究対象となる事例が数多く報告されている. 平成元 年以降，セメント系改良土を用いる工法として事前混 合処理工法が開発された ${ }^{6}$ 。この工法は，土砂等にあ らかじめ少量のセメント系安定材を混合し，所定の場 所に運搬して打設し, そのままの状態で安定した埋立 地盤を造成する工法である，主として人工島建設に多 く用いられている（例えば，東京湾横断道路における 川崎人工島や木更津人工島の建設)。事前混合処理工法 は，スラリー系とドライ系に分類され，土質材料とし て砂質土を用いる場合が多いが，スラリー系では，砂 質土のほか, 泥岩スラリー, 石炭灰, 火山灰なども用 いられる。

一方, 流動化処理土は，土質材料にセメントを添加・ 混合して改良地盤を造成するという点では，セメント 系改良土のひとつに分類されるが，その開発コンセプ 卜は大きく異なる，すなわち，従来のセメント系改良 土による浅層混合処理工法, 深層混合処理工法, 事前 混合処理工法は，軟弱地盤や液状化防止対策としての 地盤改良工法あるいは構造物の基礎，盛土の安定，土 留め擁壁への適用, 掘削時の安定性の確保などへの適 用，さらには人工島の埋立，ケーソン等の護岸背後の 裏埋工，海中盛土工などの工法として用いられてきた のに対し，流動化処理工法は，主として地下鉄や埋設 管などの地中構造物の建設の埋戻しで締固めを伴う山 砂・水締めという従来の埋戻し工法に替わるもので, 締 固め不要な「土のコンクリート工」として開発された ものである．また，原地盤にセメントを強制攪汼混合 するのではなく，事前に土質材料とセメントを混合し スラリー状にして埋戻すという点では，スラリー系の 事前混合処理工法と同様であるが，事前混合処理工法 では，主として良質の砂質土を用い，流動性が小さい のに対し, 流動化処理工法では, 掘削発生土という必 ずしも良質ではない土質材料を用いること，すなわち， より軟弱で高含水比な泥状土の密度を調整して適度な 流動性を持たせ，長距離圧送や隙間への充填性を考慮 している点が異なる7).

流動化処理工法は, 平成 5 年 8 年の 4 年間, 建設省 総合技術開発プロジェクト「建設副産物の発生抑制・再 生利用技術の開発」の一環として，当時の建設省土木 研究所と日本建設業経営協会中央技術研究所によって 実施された流動化処理土の利用技術に関する共同研究 により，流動化処理工法の効用とその実用性の第一段 階の確認を実施している ${ }^{8)}$. プロジェクト終了後, 平 成 9 年に, この共同研究に参画した企業を中心に「流 動化処理工法研究機構」が設立され，一般に広く使用 されるようになってきた。図-1 に平成 6 年〜平成 16 年までの流動化処理土の施工実績を示す ${ }^{9)}$ 。この 11 年

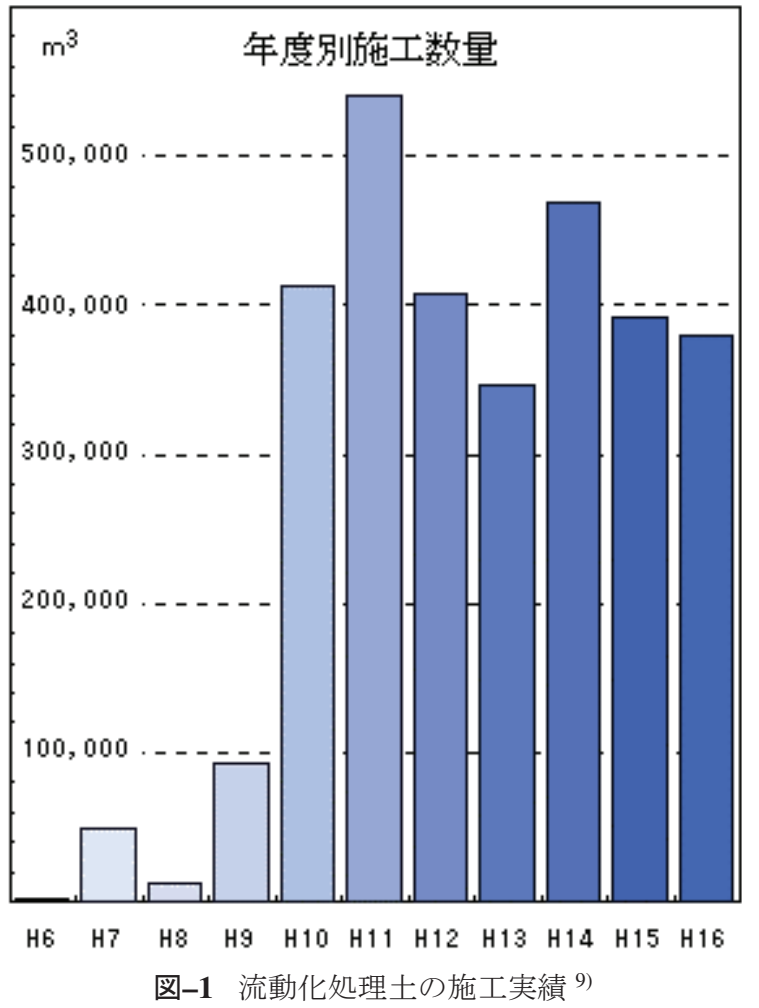

間で, 総施工量は約 310 万 $\mathrm{m}^{3}$ に達し, 平成 10 年以降 の年間施工量は平均で 40 万 $\mathrm{m}^{3}$ 程度で推移している.

流動化処理土の適用用途は，地下鉄開削部や共同溝 あるいは地中埋設管や建築基礎の狭险箇所の埋戻し， 建築基礎地盤や路面下の空洞充填や廃坑の充填, 橋台 などの構造物の裏込め, さらには地下鉄複線シールド トンネルのインバート部への充填など, 適用範囲は拡 がる傾向にあるが，平成 6 年〜平成 16 年の総施工量の 約 50\%は，地下鉄工事に伴う需要によるものである ${ }^{9}$.

流動化処理土の利用が拡大してきた理由のひとつに, 国の循環型社会政策が挙げられる。すなわち，これま で豊かな社会を支えるために大量生産・大量消費・大 量廃棄システムを継続してきたが，狭い国土のわが国 は，廃棄物の最終処分場のひっ迫などの環境制約，将 来的な鉱物資源の枯渇に対する懸念などの資源制約と いった問題に直面し, 廃棄物・リサイクル問題が社会 的に大きくクローズアップされた. 平成 12 年には, 基 本的枠組み法として循環型社会形成推進基本法が施行 され，一連の廃棄物・リサイクル法体系が順次整備さ れた。特に，建設分野では，建設リサイクル法（建設 工事に係る資材の再資源化に関する法律）が制定され， また，廃棄物処理法の改正によって，建設発生土の再 利用の促進が図られたため, 掘削発生土の有効利用に 適した流動化処理工法が広く用いられるようになった と考えられる.

図-1 を見ると，平成 14〜16 年の施工実績はわずか に減少傾向にあるが，今後の動向として，掘削工事の 
埋戻しが発生する箇所では，流動化処理土の利用がさ らに増加する傾向にあると思われる。これは，国土交 通省において平成 14 年に通達された「建設リサイクル 計画 2002」で国の直轄工事では建設発生土を積極的に 利用することが謳われており，平成 15 年には「建設発 生土等の有効利用に関する行動計画」が示され，この 中で具体的な目標指標として利用土砂の建設発生土利 用率 $(=($ 土砂利用量のうち土質改良を含む建設発生土 利用量)/土砂利用量）を，平成 17 年度には $80 \%$ (平成 12 年度実績, $62 \%)$, 平成 22 年度には $95 \%$ という数值 目標を掲げていることから推察される。なお，流動化 処理工法は, 平成 15 年にグリーン購入法特定調達品目 に建設污泥再生処理工法として認定された。

一方，流動化処理工法に関する取扱い方法などのマ ニュアル類の整備も進んでいる．平成 9 年に建設省土 木研究所で「流動化処理土利用技術マニュアル」が刊行 され，流動化処理土の用途別要求品質が示された。 そ の後, 各地方自治体における建設発生土のリサイクル ガイドラインや利用技術指針などが順次整備されてい る. また, 平成 17 年には (財) 鉄道総合技術研究所から 「鉄道構造物に用いる流動化処理士の設計マニュアル」 が刊行された。

近年，セメント系固化材による改良土では，対象土 質や配合条件により，土壌環境基準 $(0.05 \mathrm{mg} / l)$ を超え る六価クロムの溶出が認められる場合が報告され，平 成 12 年 3 月には旧建設省, 旧運輸省, 農林水産省など から「セメントおよびセメント系固化材の地盤改良へ の使用及び改良土の再利用に関する当面の措置につい て」の通達が出され，その後，平成 13 年 4 月には国土 交通省より「セメント及びセメント系固化材を使用し た改良土の六価クロム溶出試験要領（案）の一部変更」 が通達された。これにより，セメント系固化材を使用 する場合には，事前に溶出試験を実施し，六価クロム の溶出量を確認することが行われるようになった．前 述のように，大きな視点で見ると，流動化処理土はセ メント系改良土のひとつに分類されることから，流動 化処理土を利用する場合についてもセメント系固化材 による改良土と同様，環境へ与える影響が問題となっ てきている。また，適用箇所によっては，永久構造物 となることから，長期安定性の問題も指摘されている.

これらの問題は, 最近, 特に注目されはじめた事項で
あり，この分野における今後の研究成果が待たれると ころである。したがって，本論文では，筆者が行って きた研究を中心に，かなりの部分で明らかになってき た流動化処理土の力学特性について論じるものである.

\section{3. 流動化処理土の力学特性}

本来, 流動化処理土は, 各種構造物の裏込めや埋設物 の埋戻しで十分な締固めが行えないような場合に, 建 設発生土を使用可能なようにするために開発されたも のである。現地で利用できない土には，細粒分を多く 含み，高含水比の場合が多く，固化材を添加して作製 される流動化処理土の密度が小さくなることが懸念さ れる。このような流動化処理土は，水と固化材による セメンテーションによって構造骨格が保たれていると 考えられ，乾燥すると極めて脆い地盤材料になってし まうので，地下水以浅で乾燥するような箇所での使用 には適さない。基本的には，東京湾横断道路で使用さ れたセメント改良工法のうちのスラリー系の事前混合 処理工法 ${ }^{10), 11)}$ に似たような性質を持つと考えられる.

本章では，横浜市のみなとみらい線建設における開 削トンネルの埋戻しを目的として作製された低強度流 動化処理土およびシールドトンネルのインバート材と しての利用を目的として作製された高強度流動化処理 土の力学特性について述べる。

\section{（1）低強度流動化処理土の三軸せん断特性}

低強度流動化処理土は，開削トンネル等の埋戻し材 として用いるものである，埋戻し材は，再掘削が行わ れる可能性があることから，一軸圧縮強さを $490 \mathrm{kPa}$ 以 下に設定される場合が多い，以下に，低強度流動化処 理土の三軸せん断特性について述べる 12)-15)。

試験に用いた現場発生土は，シルト質粘性土であり， 多数の貝殼等を含んでいるため，泥水を作製する際に $2 \mathrm{~mm}$ ふるいで調整した。流動化処理土の作製は, 所定 の条件（フロー值 $200 \mathrm{~mm}$ 以上，ブリージング率 $1 \%$ 以 下，一軸圧縮強さ $\left.q_{28}=196 \sim 490 \mathrm{kPa}\right)$ による配合試験 結果に基づいて ${ }^{12)}$, 設計泥水密度を $1.2 \mathrm{~g} / \mathrm{cm}^{3}$ とし, 固 化材はセメント系固化材一般軟弱土用を用いた。さら に, 山砂を添加して流動化処理土の密度を増大させた 配合の試料についても検討を加えた，表-1には，設計

表-1 設計配合の例

\begin{tabular}{|c|c|c|c|c|c|c|c|c|c|}
\hline 配合 & $\begin{array}{c}\text { 泥水密度 } \\
\left(\mathrm{g} / \mathrm{cm}^{3}\right)\end{array}$ & $\begin{array}{c}\text { 処理土密度 } \\
\left(\mathrm{g} / \mathrm{cm}^{3}\right)\end{array}$ & $\begin{array}{c}\text { 粘性土 } \\
(\mathrm{kg})\end{array}$ & $\begin{array}{c}\text { 含水比 } \\
(\%)\end{array}$ & $\begin{array}{l}\text { 水 } \\
(\mathrm{kg})\end{array}$ & $\begin{array}{l}\text { 砂 } \\
(\mathrm{kg})\end{array}$ & $\begin{array}{c}\text { 含水比 } \\
(\%)\end{array}$ & $\begin{array}{l}\text { セメント系 } \\
\text { 固化材 }(\mathrm{kg})\end{array}$ & 泥水混合比 \\
\hline 配合 1 & \multirow{3}{*}{1.20} & 1.24 & 541 & 71.4 & 636 & 0 & - & \multirow{3}{*}{59} & - \\
\hline 配合 2 & & 1.30 & 493 & 65.9 & 616 & 132 & 9.96 & & 8.40 \\
\hline 配合 3 & & 1.40 & 446 & 65.9 & 557 & 338 & 9.96 & & 2.97 \\
\hline
\end{tabular}




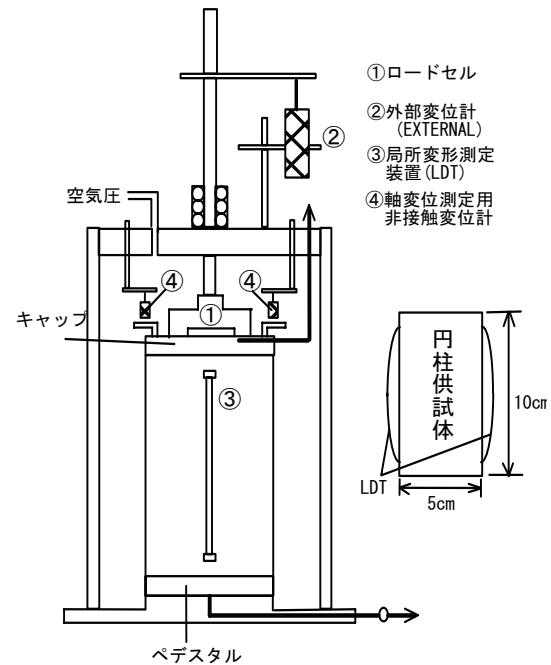

図-2 三軸試験機の概略図

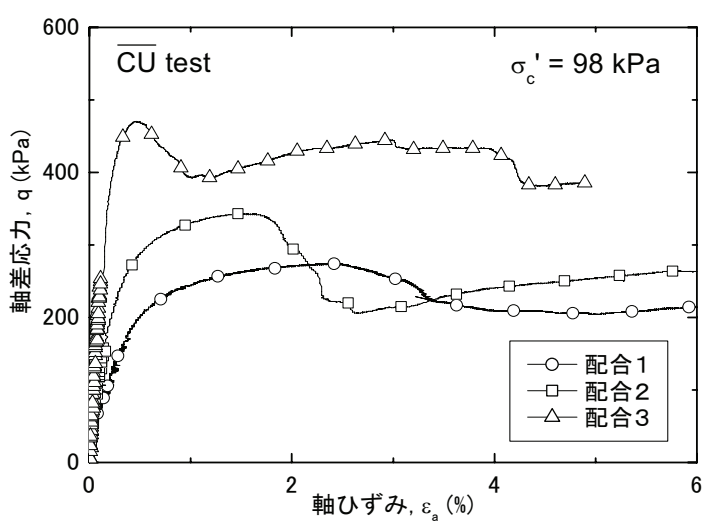

図-3 軸差応力〜軸ひずみ関係

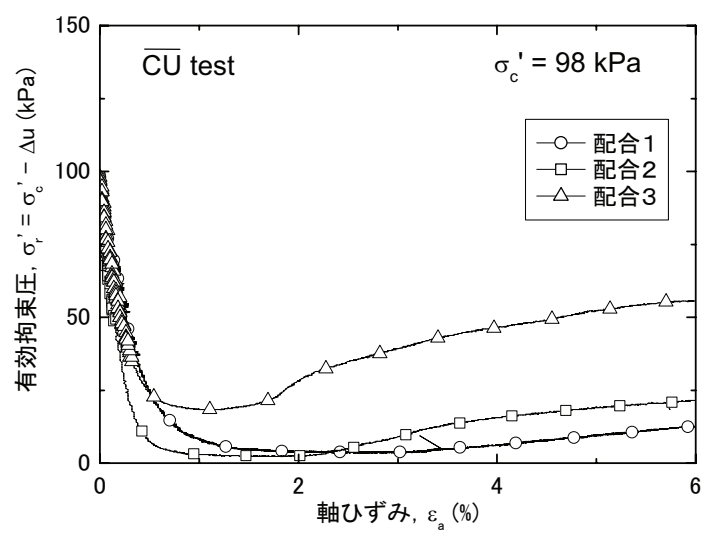

図-4 有効拘束圧〜軸ひずみ関係

配合の一例を示す，試験は，図-2 に示すように円柱供 試体（高さ $10 \mathrm{~cm}$, 直径 $5 \mathrm{~cm}$ ）を用いた三軸試験装置に よって 49, 98, $196 \mathrm{kPa}$ の拘束圧で，圧密非排水三軸圧 縮試験をひず夕速度 $0.01 \% / \mathrm{min}$ にて実施した。軸変位 測定には，上部キャップの変位を測定する非接触変位 計，および供試体上下端面での緩み層（ベディングエ ラー）の影響を含まない正確な軸ひずみを供試体側面に おいて測定する局所変形測定装置（Local Deformation Transducer）16）をそれぞれ用いた。 図-3 に，配合 1〜3

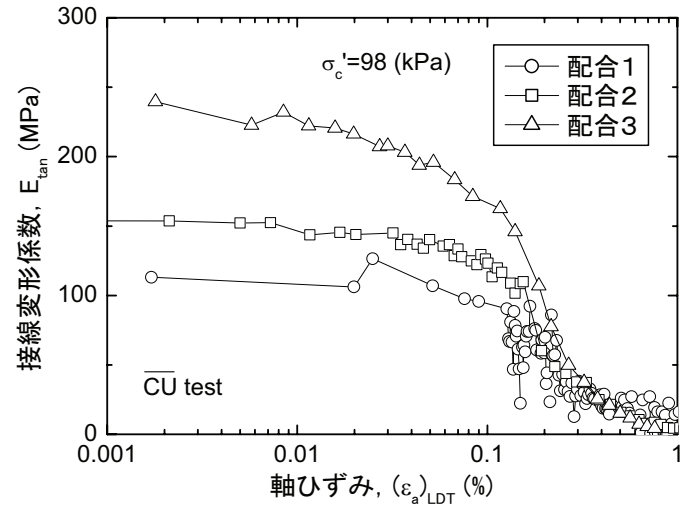

図-5 $E_{\tan }$ のひずみレベル依存性

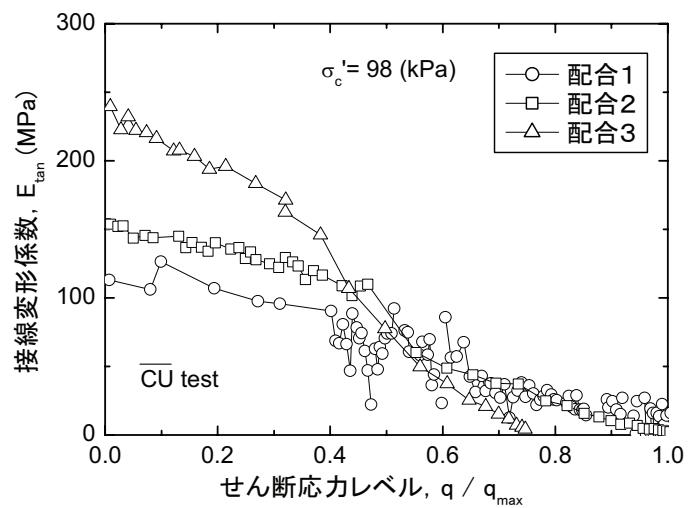

図-6 $\quad E_{\tan }$ のせん断応力レベル依存性

の拘束圧 $\sigma_{c}^{\prime}=98 \mathrm{kPa}$ での軸差応力〜軸ひずみ関係を, 図-4にはせん断中の有効拘束圧と軸ひずみの関係をそ れぞれ示す. 砂の添加量が多いほど, すなわち処理土 密度が大きいほじ，最大軸差応力 $q_{\max }$ が大きい. 図-4 を見ると, せん断初期からピーク強度に至るまでの過 剰間隙水圧の発生が極めて大きく, 処理土密度やせん 断開始時の有効拘束圧の值にかかわらずピーク強度時 （ $q_{\max }$ 時）の有効拘束圧はほとんどゼロになっている (後述の図-8 参照)。しかし，ピーク強度以降は，有効 拘束圧が増加傾向にあり, 残留強度がある程度大きく なるため，一軸試験での有効応力状態とは異なってく る.これは，セメント改良土と類似の傾向である ${ }^{17)}$. 図-5 には, 配合 $1 \sim 3$ における $\sigma_{c}^{\prime}=98 \mathrm{kPa}$ の軸差応 力〜軸ひずみ曲線の接線勾配から得られた接線変形係 数 $E_{\mathrm{tan}}$ のひずみレベル依存性を示す. 配合 1,2 では軸 差応力〜軸ひずみ曲線の接線勾配である $E_{\tan }$ が，軸ひ ずみ $0.05 \%$ 程度までほぼ一定值を示していることから， 軸差応力〜軸ひずみ関係は線形的であり，その変形特 性は線形性が大きいと言える。一方，配合 3 では軸ひ ずタ $0.01 \%$ 程度から $E_{\tan }$ が減少傾向を示していること から，軸差応力〜軸ひずみ関係は非線形であり，その 変形特性は配合 1,2 の変形特性に比べて非線形性が増 加している傾向にある. 図-6 は， $E_{\mathrm{tan}}$ のせん断応力レ ベル依存性の比較である。配合 1,2 では，ピーク強度 


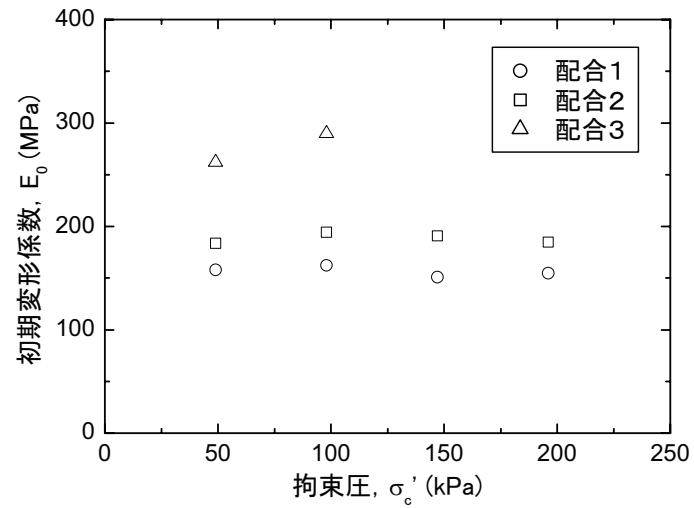

図-7 初期変形係数の拘束圧依存性

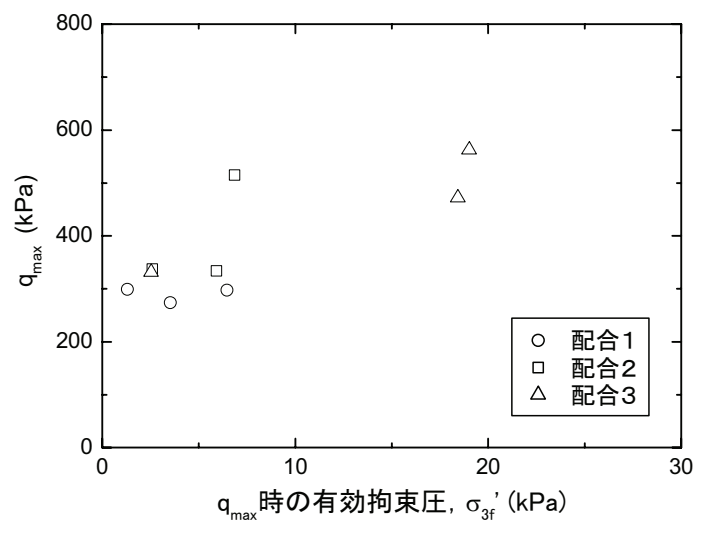

図-8 $q_{\max }$ と $q_{\max }$ 時の有効拘束圧の関係

の $40 \%$ 程度まで $E_{\mathrm{tan}}$ の減少率が小さいのに対して, 配 合 3 の $E_{\mathrm{tan}}$ の減少率はピーク強度の $20 \%$ 程度以降で大 きくなっている.すなわち, 配合 3 のせん断応力レベ ル依存性は配合 1,2 のそれに比べて大きい. 図-7 は, 等方圧密過程で拘束圧 49, 98, 147, $196 \mathrm{kPa}$ における軸 ひずみ $4 \times 10^{-5}$ レベルでの微小な繰返し載荷を行って 得られた初期変形係数 $E_{0}$ の拘束圧依存性を示してい る. $\sigma_{c}^{\prime}=49 \sim 196 \mathrm{kPa}$ の範囲での $E_{0}$ について見ると， 全体的な傾向としては，配合種類によらず $E_{0}$ の拘束圧 依存性は見られないようである。これはセメント改良 土と類似の傾向であり ${ }^{17)}$ ，セメントを添加した地盤材 料はセメンテーションにより，微小ひずみレベルでの 変形特性が弾性的になることを示している。図-8 は, $q_{\max }$ と $q_{\max }$ 時の有効拘束圧の関係である. 非排水三軸 圧縮試験で得られた $q_{\max }$ の值の範囲は, 配合設計で設 定した一軸圧縮強さの範囲（196～490 kPa）にほぼ等 しい值を示している。これは，ピーク強度状態におい て有効拘束圧の值がほぼゼロに近い一軸試験と同様な 有効応力状態にあるということに対応している。しか し, 前述したようにピーク強度以降は, 一軸試験での 有効応力状態とは異なってくる.

\section{(2) 高強度流動化処理土の繰返し変形特性}

高強度流動化処理土は，主としてシールドトンネル
のインバート材に使用されるものである.インバート 材としての高強度流動化処理土の研究は, 泥水シール ドからの発生土を利用したインバート材の開発に関し て, 強度特性や流動性, 而久性などの検討が報告され ているが ${ }^{18)}$, 掘削発生土を利用した高強度流動化処理 土の繰返し載荷耐久性などの変形特性については未解 明な部分が多い。ここでは, 目標とする一軸圧縮強さ を $1.96,5.88 \mathrm{MPa}$ とした高強度配合による流動化処理 土に対して種々の条件で繰返し載荷を実施した結果に ついて述べる ${ }^{19)-20) .}$

試験に用いた試料は，シルト質粘性土であり，多数の 貝殸等を含んでいるため, 泥水を作製する際に $2 \mathrm{~mm}$ ふ るいで調整した。流動化処理土の作製は, 所定の条件 （フロー值 $200 \mathrm{~mm}$ 以上，ブリージング率 $1 \%$ 以下，処 理土密度 $1.5 \mathrm{~g} / \mathrm{cm}^{3}$ 以上，一軸圧縮強さ $q_{28}=1.96$ (以 下, タイプ 20), 5.88 (以下, タイプ 60) $\mathrm{MPa}$ )による 配合試験結果に基づいて固化材はセメント系固化材一 般軟弱土用を用いた。実験は，直径 $30 \mathrm{~cm}$, 高さ $60 \mathrm{~cm}$ の円柱供試体に対する水浸および湿潤状態での一軸繰 返し載荷試験（図-9 (a), (b)）と直径 $50 \mathrm{~cm}$, 深さ $30 \mathrm{~cm}$ の模型土層による水浸状態での繰返し載荷試験（図-9 (c)）を実施した. 水浸状態での一軸繰返し載荷試験で は，供試体の側方が拘束されない状態での載荷試験で あるが，実際のインバート部分はセグメントなどによ り側方に拘束された状態にあると考えられる。模型土 層による水浸状態での繰返し載荷試験は, 原位置の応 力状態に近いと考えられる模型土槽に高強度流動化処 理土を直接，打設することにより側方が拘束されてい ると考えられる状態での変形特性を把握・検討するた めに実施した。

実施した一連の試験の載荷条件は, 載荷周波数 $20 \mathrm{~Hz}$ の正弦波で, 繰返し載荷回数 150 万回まで繰返し載荷 応力の両振幅を $98 \mathrm{kPa}$ として, 一定の載荷振幅による 繰返し載荷試験（載荷振幅一定）と, 所定の繰返し載 荷回数に達した後に載荷両振幅を段階的に増加させる 繰返し載荷試験（載荷振幅増加）の 2 種類の試験を実 施した．載荷振幅を増加させる荷重ステップは，1～10 万回を $98 \mathrm{kPa} ， 10$ 万回 50 万回を $196 \mathrm{kPa} ， 50$ 万回〜 75 万回を $294 \mathrm{kPa} ， 75$ 万回〜 100 万回を $392 \mathrm{kPa} ， 100$ 万回〜 150 万回を $490 \mathrm{kPa}$ の載荷振幅となるように設 定した。一般に, 有道床軌道の場合, まくら木下面で の圧力は $98 \mathrm{kPa}$ であるが，道床の剛性が大きくなるほ ど，まくら木下面での圧力は増大寸ることが知られて いる. 本軌道構造は, まくら木の下に厚さ $30 \mathrm{~cm} の コ$ ンクリート路盤が施工される計画であるため，コンク リート路盤下の圧力は，強化路盤の設計に用いる路盤 圧力程度と考えてよい. したがって, 輪重 $8.3 \mathrm{t}$, 道床 厚 $25 \mathrm{~cm}, \mathrm{PC} 3$ 号まくら木を想定した場合, 路盤圧力 


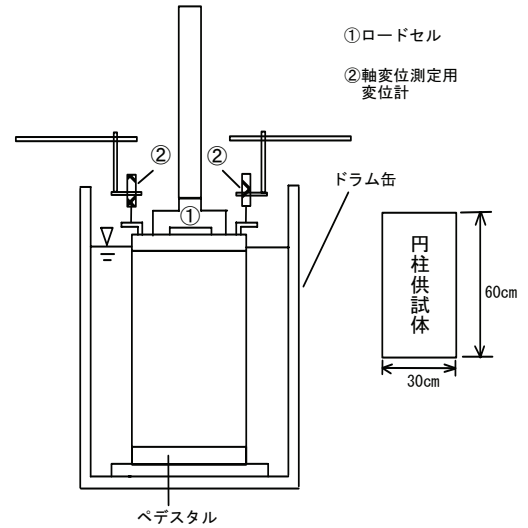

(a) 水浸一軸繰返し載荷試験

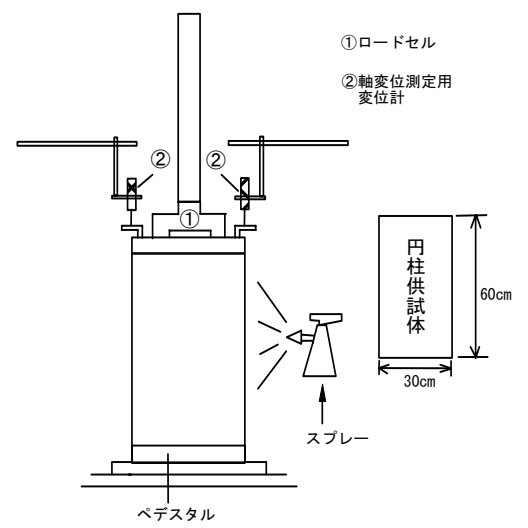

(b) 湿潤一軸繰返し載荷試験

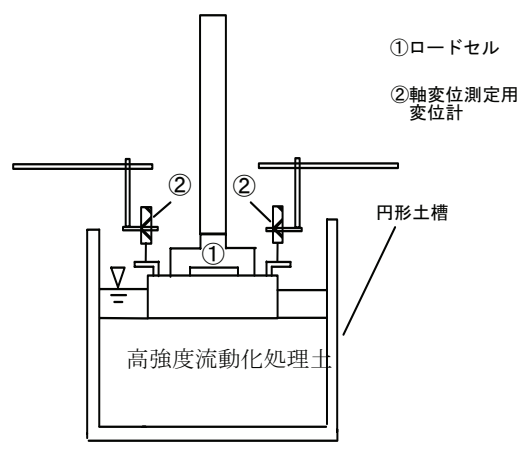

(c) 模型土槽繰返し載荷試験

図-9 各試験装置の概略図

が $98 \mathrm{kPa}$ を超えるのは, 列車速度が $150 \mathrm{~km} / \mathrm{h}$ であるこ とから, 試験で設定した繰返し載荷応力幅は安全側で あると考える．供試体の試験開始時の材令を 28 日とし て, 水浸状態での試験では水浸開始材令を 24 日に設定 した。

図-10には，タイプ 20 の繰返し試験結果を, 図-11 にはタイプ 60 の繰返し試験結果をそれぞれ示す。水浸 状態での試験結果を見ると, 載荷振幅一定として列車 荷重相当の繰返し載荷によって生じる 150 万回での沈 下量は, タイプ 60 で $0.11 \mathrm{~mm}$, タイプ 20 で $0.17 \mathrm{~mm}$ で あり，極めて少ない沈下量である。一方, 載荷振幅を増 加させる試験では, 100 万回以降に載荷振幅を, $490 \mathrm{kPa}$

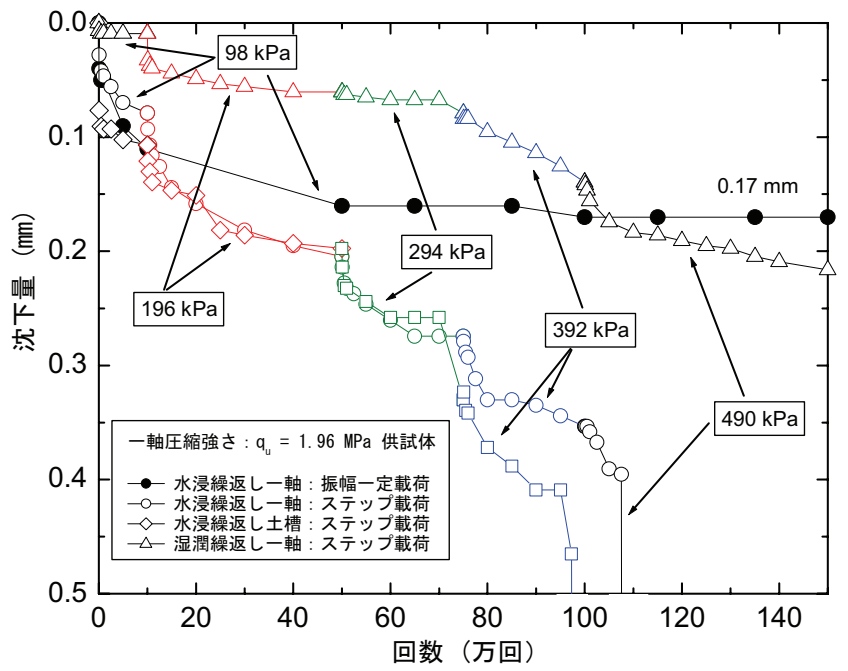

図-10 タイプ 20 の繰返し試験結果の比較

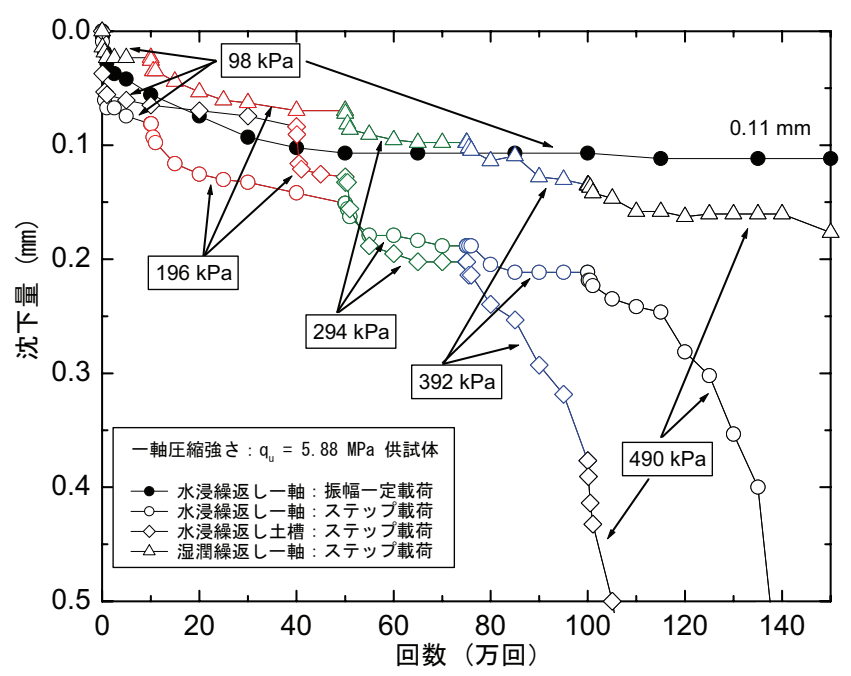

図-11 タイプ 60 の繰返し試験結果の比較

としたところで沈下量が急激に増大し, 最終的に崩壊 に至っている，すなわち，図-10に示すタイプ 20 では, 載荷振幅を $490 \mathrm{kPa}$ とすると同時に崩壊に至る結果で あり，また，載荷振幅を $392 \mathrm{kPa}$ とした場合にも崩壊の 兆候が見られたが，タイプ 60 では，載荷振幅を $490 \mathrm{kPa}$ とすると沈下が進行するものの崩壊には至らなかった。 したがって, タイプ 20 の一軸圧縮強さ $1.96 \mathrm{MPa}$ の供 試体に対して，392～490 kPa の限界応力を示すと考え， 本実験で用いた高強度流動化処理土の变形に対する限 界応力は，一軸圧縮強さの 20～25\%程度であると言え る. 各載荷条件での載荷振幅 $98 \mathrm{kPa}$ で 50 万回までに 発生する沈下量を比較すると, 湿潤状態での沈下量が 最も小さく, 水浸状態での沈下量は一軸, 模型土槽とも に同程度となっている．また，150万回での沈下量を 比べると, 湿潤状態での繰返し載荷では, 載荷振幅を $490 \mathrm{kPa}$ に設定したにもかかわらず，載荷振幅を $98 \mathrm{kPa}$ で一定とした水浸状態の繰返し載荷試験による沈下量 と大きく違わない. ただし, 載荷振幅を $490 \mathrm{kPa}$ では 
沈下量の収束傾向が見られないことに注意する必要が ある。このことから，高強度流動化処理土の変形特性 は，湿潤状態にあれば極めて良好であることがわかる。 水浸一軸繰返し載荷試験結果と模型土槽における繰返 し載荷試験結果を比較すると, タイプ 20 では, 沈下量 〜載荷回数関係が載荷振幅 $294 \mathrm{kPa}$ まではほぼ一致し ている. タイプ 60 では, 模型土槽の繰返し載荷試験に おいて 1〜40 万回を $98 \mathrm{kPa}$ での載荷振幅としたため直 接的には比較できないが，40 万回～50 万回での沈下量 の発生傾向をみると，ほぼ同じであることから，タイ プ 20 と同様に, 載荷振幅 $294 \mathrm{kPa}$ までの沈下量〜載荷 回数関係はほぼ一致するものと考えられる。

\section{4. 繊維材混合流動化処理土の力学特性}

流動化処理土は，セメント安定処理土と同様に固化 材添加量を増やして強度を増加させると, 脆性的な挙 動を示し耐震性能の低下が生じる恐れがある。また， 強度の増加は再掘削が必要な箇所への適用を困難にさ せる等の指摘がなされている。したがって，種々の土 構造物に適用可能で, 地震に対して粘り強く耐え得る ような地盤材料とするためには，流動化処理土の靭性 能を向上させることが望まれている。

本章では，靭性の向上をはかる目的で流動化処理土 に纎維質材料として粉砕した古紙を泥水に混合するこ とによって ${ }^{21)}$ ，補強効果が期待できる䋊維材混合流動 化処理土の力学特性について述べる 22)-24).

\section{(1) 配合試験}

試験に用いた試料は，均質性を考慮して，物理的性 質が明らかになっている市販の粘性土 NSF-CLAY であ る。表-2にその物理的性質を示す。また，固化材には 一般軟弱土用セメント系固化材を用いた。添加する繊 維質材料には細かく粉砕した綿状新聞紙， $2 \times 10 \mathrm{~mm}$ の短冊状に裁断した新聞紙および普通紙を用いた。配 合ケースの一覧を表-3 に示す。なお，短冊状新聞紙を 添加したケースでは， $15 \mathrm{~kg} / \mathrm{m}^{3}$ 以上添加すると繊維質 材料が団粒状になり均質に混合できなかった.

一軸圧縮試験には直径 $50 \mathrm{~mm}$, 高さ $100 \mathrm{~mm}$ の円柱供 試体を用い, 養生日数 7，14，21，28 日で試験を行った。 なお，軸ひずみの測定には，供試体端面の乱れやゆるみ 層のために生じるべディングエラーのない正確なひず みを求めるために局所変形測定装置 (Local Deformation Transducer, LDT) を用いた． 綿状新聞紙はシュレッダー にて裁断した後，加水してフードプロセッサーにより 粉砕したものを炉乾燥することによって作製した。ま た，本研究では供試体の再現性を高めるために配合時 においてパラメータが少なく比較的作製容易な泥水式
表-2 NSF-CLAY の物理的性質

\begin{tabular}{ll|l}
\hline 土粒子密度 & $\rho_{s}\left(\mathrm{~g} / \mathrm{cm}^{3}\right)$ & 2.762 \\
\hline 液性限界 & $w_{L}(\%)$ & 60.15 \\
\hline 塑性限界 & $w_{p}(\%)$ & 35.69 \\
\hline 塑性指数 & $I_{p}$ & 24.46 \\
\hline
\end{tabular}

表-3 配合ケース一覧

\begin{tabular}{|c|c|c|c|}
\hline 紙種 & \multicolumn{2}{|c|}{ 新聞紙 } & 普通紙 \\
\hline 添加量 & 綿 状 & 短冊状 & 短冊状 \\
\hline $0\left(\mathrm{~kg} / \mathrm{m}^{3}\right)$ & \multicolumn{3}{|c|}{0} \\
\hline $5\left(\mathrm{~kg} / \mathrm{m}^{3}\right)$ & 0 & 0 & 0 \\
\hline $10\left(\mathrm{~kg} / \mathrm{m}^{3}\right)$ & 0 & 0 & 0 \\
\hline $15\left(\mathrm{~kg} / \mathrm{m}^{3}\right)$ & 0 & $x$ & - \\
\hline $20\left(\mathrm{~kg} / \mathrm{m}^{3}\right)$ & 0 & $x$ & $\bigcirc$ \\
\hline
\end{tabular}

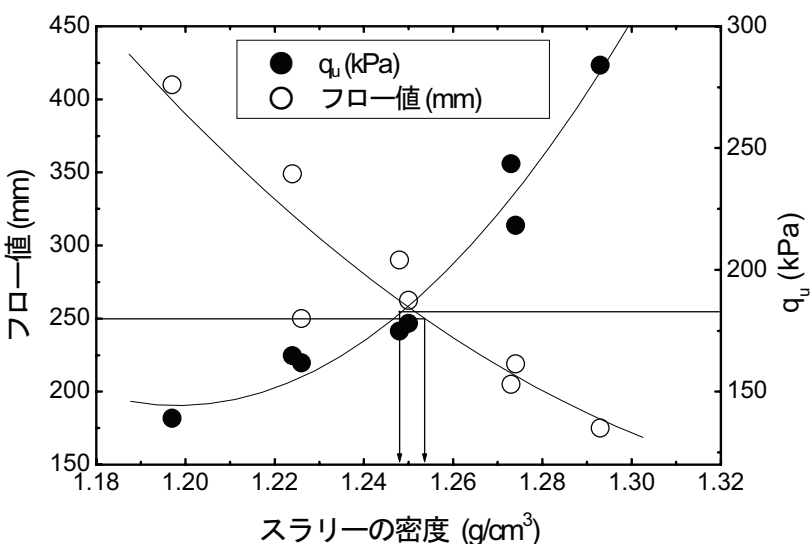

図-12 配合試験結果

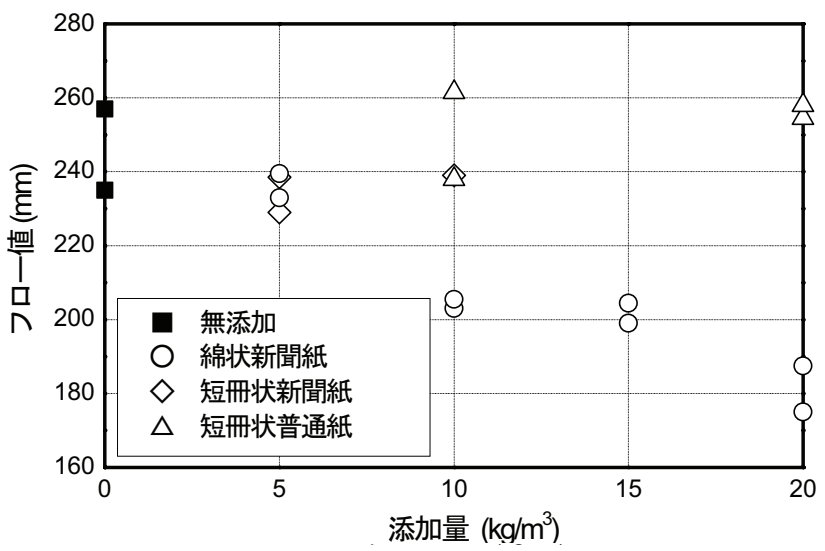

図-13 繊維質材料添加量とフロー值の関係

流動化処理土とした。配合は, 28 日養生後の目標一軸 圧縮強さ $q_{u}$ を $180 \mathrm{kPa}$, 流動性の指標であるフロー值 を $250 \mathrm{~mm}$ として配合試験により決定した。配合試験 は, 初めに固化材添加量を泥水 $1 \mathrm{~m}^{3}$ 当たり $100 \mathrm{~kg}$ に 設定して行った。 その結果, 目標強度を満たすことが できなかったため, 固化材添加量を外割で $200 \mathrm{~kg}$ とし 泥水密度を変化させ，目標值を満たす泥水密度である $\rho_{f}=1.250 \mathrm{~g} / \mathrm{cm}^{3}$ に決定した. 配合試験による泥水密 度 $\rho_{f}$, フロー值, 一軸圧縮強さ $q_{u}$ の関係を図-12 に示 す. 図-13 は，䋊維質材料添加量とフロー值の関係を 


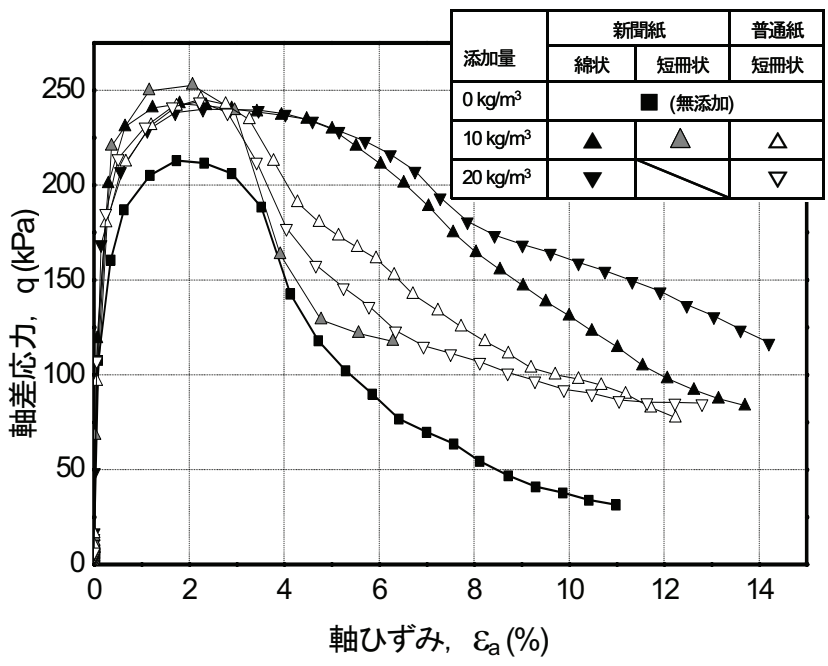

図-14 軸差応力ー軸ひずみ関係

示している．綿状新聞紙を添加したケース（○）では， 添加量の増加に伴ってフロー值が線形的に減少寸る傾 向を示している．これに対して短冊状新聞紙を添加し たケース $(\diamond)$ および短冊状普通紙を添加したケース

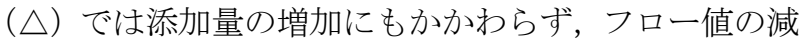
少は，概朊られないようである。この結果より，繊 維材混合流動化処理土の流動性には添加寸る繊維質材 料の形状が大きく影響することが考えられ，特に本研 究で行った条件では綿状新聞紙の影響が最も大きい.

\section{(2) 一軸圧縮試験による力学特性}

図-14 は, 繊維材無添加, 添加量 $10 \mathrm{~kg} / \mathrm{m}^{3}$ および $20 \mathrm{~kg} / \mathrm{m}^{3}$ の繊維質材料を変化させたケースの軸差応力 と軸ひずみの関係を比較したものである。一軸圧縮強 さ $q_{u}$ に注目すると, 無添加のケースと比較して, 䋊維 質材料を添加したケースでは添加した繊維質材料の種 類によらず，約 $10 \%$ 大きな強度が得られた。 ピーク後 は, 無添加のケースでは急激に強度が減少し, 軸ひずみ $10 \%$ 以降では $50 \mathrm{kPa}$ 未満となっているのに対して，短 冊状の繊維質材料を添加したケースではピーク直後か ら強度の減少が見られるものの, その減少量は無添加の ケースに比べて小さく，軸ひずみ $10 \%$ 以降でも $100 \mathrm{kPa}$ に近い強度を維持している. さらに綿状の繊維質材料 を添加したケースでは，ピーク後も軸ひずみ $5 \%$ 付近ま で強度を維持し, その後緩やかな減少傾向に転じてい る．また，軸ひずみ 10\%に至っても $130 〜 160 \mathrm{kPa}$ の強 度を維持している。すなわち, 繊維質材料の形状によ らず脆性的性質の改善効果は見られるが，特に綿状新 聞紙を添加したケースで最も大きい。

写真-1 (a)〜 (c) は, それぞれ繊維材無添加, 綿状新 聞紙 $\left(20 \mathrm{~kg} / \mathrm{m}^{3}\right)$, 短冊状普通紙 $\left(20 \mathrm{~kg} / \mathrm{m}^{3}\right)$ の試験終 了時の破壊状況の写真である. 写真-1 (a) の無添加の ケースでは, 鉛直方向に亀裂が生じて破壊に至ったが,

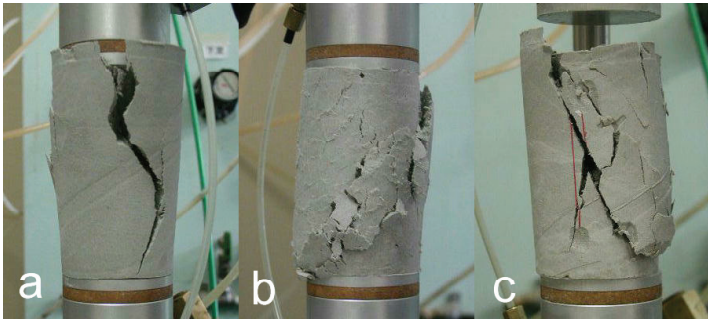

写真-1 供試体の破壞状況

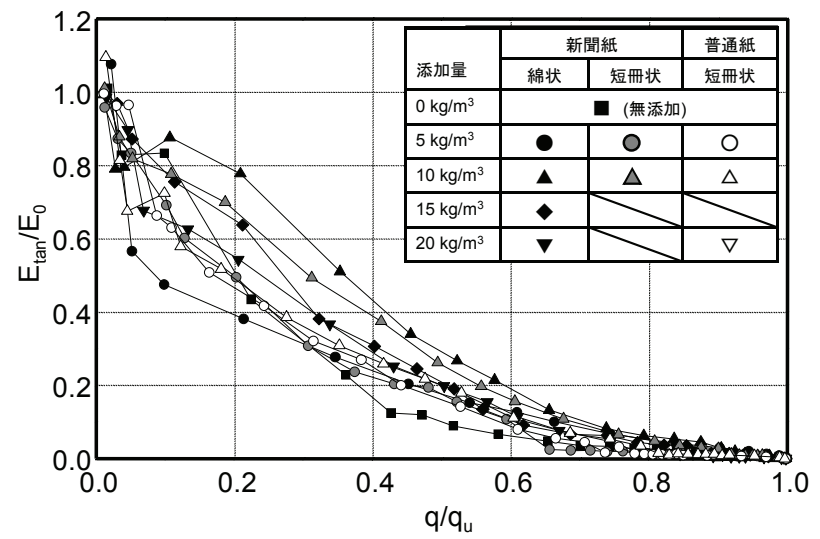

図-15 $E_{\tan } / E_{0}$ と $q / q_{u}$ の関係

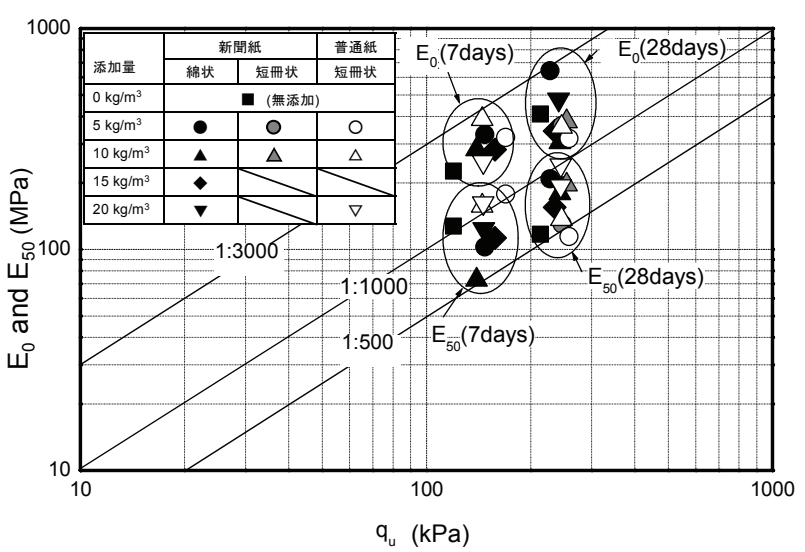

図-16 $E_{0}$ および $E_{50}$ と $q_{u}$ の関係

写真-1 (b) の綿状新聞紙を添加したケースでは表面に 細かいシワ状の亀裂が生じて破壊に至っている。また, 写真-1 (c) の短冊状普通紙を添加したケースでは, 添 加量が等しいのにもかかわらず綿状新聞紙のケースと は異なり，細かい亀裂が見られず，斜め方向に明瞭な 破壊面が生じている。この明瞭な破壊面は, 短冊状新 聞紙を添加したケースにも見られることから，破壊性 状は添加する繊維質材料の形状によるところが大きい と思われる。また, 細かい亀裂が生じた綿状新聞紙を 添加したケースの脆性的性質の改善効果が最も大きい ことから，この細かい亀裂がせん断面の形成を妨げて いる状況を示していると考えられる。

図-15 に, 接線変形係数 $E_{\mathrm{tan}}$ を初期変形係数 $E_{0}$ で正 規化した $E_{\mathrm{tan}} / E_{0}$ と, 応力レベル $q / q_{u}$ の関係を示す. $E_{\mathrm{tan}} / E_{0}$ はいずれのケースにおいても載荷とともに減少 
し，非線形的な関係となっている．䋊維質材料の違い による比較においては明瞭な差違は見られない。図-16 は， $E_{0}$ および $E_{50}$ と $q_{u}$ の関係である。繊維質材料の 種類によらず $E_{0}$ は $1000 \sim 3000 q_{u}(\mathrm{kPa}), E_{50}$ は 500 $\sim 1000 q_{u}(\mathrm{kPa})$ の值を得た. 既往の研究では ${ }^{25)}$, LDT を用いて測定したセメント改良土の場合， $E_{0}$ はおよそ $3000 q_{u}(\mathrm{kPa}), E_{50}=100 \sim 1000 q_{u}(\mathrm{kPa})$ の関係が報告 されており, 本研究で用いた䋊維材混合流動化処理土 も類似の関係となった。

\section{5. 今後の課題と展望}

本論文では, 流動化処理土の施工実績と動向, 流動化 処理土と耐震性向上を目的として靭性能を改善した繊 維材混合流動化処理土の力学特性について論じた. 力 学特性に関しては，以下に示す知見を得た。

（1）シルト質粘性土による低強度流動化処理土に対し て圧密非排水三軸圧縮試験を実施し, その力学特性 を検討した結果, 載荷初期からピークに至るまで過 剰間隙水圧が増加して，ピーク時の過剰間隙水圧は 拘束圧にほぼ等しくなり, 有効拘束圧がほとんどゼ 口を示すことから, 非排水状態での $q_{\max }$ は一軸圧縮 強さと同程度になると考えられること, ピーク後に は過剰間隙水圧が減少し有効拘束圧が増加傾向にあ るため, 残留強度がある程度大きくなり，一軸試験 での応力状態とは異なること等がわかった。

（2）シルト質粘性土による高強度流動化処理土に対し て実施した種々の繰返し載荷試験の結果から，水浸 状態での列車荷重相当の繰返し載荷によって生じる 150 万回での沈下量は極めて少ない沈下量であるこ と, 水浸状態での列車荷重相当の繰返し載荷によっ て沈下が進行しない限界応力は一軸圧縮強さの 20〜 $25 \%$ 程度であること, 高強度流動化処理土は, 湿潤 状態が確保されれば変形性能に対して極めて良好な 状態にあること等がわかった。

(3) 市販の NSF-Clay による低強度流動化処理土に緎 維質材を混合した繊維材混合流動化処理土に対して 実施した配合試験，一軸圧縮試験の結果から，繊維 材混合流動化処理土の流動性は, 添加する繊維質材 料の形状の影響を大きく受けること, 一軸圧縮試験 において, 繊維質材料の添加量や種類によらず一軸 圧縮強さ $q_{u}$ は無添加のケースに比べて約 $10 \%$ 増大 するが，ピーク後の脆性的性質の改善効果は綿状新 聞紙を添加したケースが最も大きいこと， $E_{0}$ および $E_{50}$ と $q_{u}$ の関係に及ぼす繊維質材料添加の影響は小 さいこと等がわかった。

上記に述べた結果から, 流動化処理土の力学特性は,
基本的にはセメント改良土と同様な物性であることか ら, 従来のセメント改良土に対して行われてきた膨大な 研究成果を活かして参考にすることができると考えら れる.また，流動化処理土に繊維材を混合するとピー ク後の応力が急減することなく, 非常に粘り強い材料 になることが示されたことから，セメント改良土にお いても繊維材を混合すれば，セメント系改良地盤の耐 震性を向上させることが可能であることが示唆された. 今後, さらなる応用が期待できるものと考えられる.

一方，東京湾横断道路に用いたセメント改良工法に は，4 種類の工法が用いられたが，それぞれの工法によ る地盤の一様性は, 事前混合処理工法 (スラリー), 深 層混合処理工法 (従来), 深層混合処理工法 (低強度), 事前混合処理工法（ドライ）の順に高いことが報告さ れている ${ }^{10)-11)}$. 流動化処理土は, 東京湾横断道路に 用いた事前混合処理工法（スラリー）による改良土に 似て，地盤の一様性が高いことが予想されるが，一般 には，混合過程や盛り立て中に均一に施工されないな どの理由から改良土地盤は非一様になる恐れがあると 言われている. しかし, 流動化処理土が実用化されて から 10 年程度しか経っていないため, 実際に施工され た流動化処理土地盤に対する詳細な原位置試験の実施 報告はあまり見られない. したがって, 今後は原位置 試験などから非一様性の程度を詳細に検討する必要が ある。

最近では，建設リサイクル法の制定などを受け，石 炭灰や鉄鋼スラグなどの再利用として, 流動化処理土 を用いる場合が見られるようになってきている。しか し, 前述のように, 流動化処理土は密度を小さくしすぎ ると多量の水を含む貧配合のモルタルになってしまい, 乾燥した場合には非常に脆くなる。したがって，作製 方法や適用箇所を誤ると, 予想外の沈下や崩壊といっ た事態を招く恐れもあることから，事前の配合試験を 十分に行うことが重要であろう。一方で，狭险な箇所 では，埋戻し材に山砂を使っても十分な締固めができ ないことから，そのような箇所への流動化処理土の利 用は極めて有効であると考えられる. 流動化処理土が 広く用いられるようになってから，まだ，日が浅いこ とから, 今後は地震時の災害時など供用中の挙動につ いて詳細な調査が必要であると思われる。

謝辞：本研究の遂行にあたっては, 独立行政法人日本 学術振興会, 財団法人鉄道総合技術研究所, みらい建 設工業株式会社, 株式会社アースプライムから研究助 成を受けた。また，財団法人鉄道総合技術研究所，村 田修氏, 神田政幸氏, みらい建設工業株式会社, 市原 道三氏には，多大な研究支援とご助言を頂いた。さら に，実験およびデータ整理には，藤川拓氏（現岩手県 
庁)，對馬広紀氏（現 岩田建設 (株)）に負うところが 大きい，末筆ながら，ここに関係各位に深甚なる感謝 の意を表す。

\section{参考文献}

1) 工藤宗治, 落合英俊, 大嶺聖 : 安定処理した火山灰質粘 性土の強度・変形特性における短繊維補強効果，第 34 回地盤工学研究発表会講演集, pp.857-858, 1999.

2) 築地健太朗, 安福規之, 落合英俊, 大嶺聖, 宮崎良彦 : プ ラスチック廃材を利用したセメント安定処理土の粘り強 さの改善, 第 33 回地盤工学研究発表会講演集, pp.22632264, 1998.

3) 山本雅之, 落合英俊, 安福規之, 大嶺聖 : プラスチック 廃材の地盤補強材としての有効利用一砂質土に対する 強度改善効果一, 第 35 回地盤工学研究発表会講演集, pp.1047-1048，2000.

4) 久野悟郎編著 : 土の流動化処理工法〜建設発生土 ・泥土 の再生利用技術，技報堂出版， 1997 .

5) 末松直幹, 杉山勝英 : 深層混合処理工法, 基礎工, Vol.11, No.2, pp.8-17, 1983.

6) 芳沢秀明, 片野英雄, 黒山英伸 : 事前混合処理工法の開 発, 土木学会第 43 回年次学術講演会講演概要集, VI, Vol.43, pp.8-9, 1988

7）地盤工学会 : セメント改良土の物性と試験方法に関する 委員会報告書第 2 章 $2.1 ， 2.2$, セメント及びセメント系 固化材を用いた固化処理土の調查・設計・施工方法と物 性評価に関するシンポジウム発表論文集, pp.2-22, 2005.

8) 久野悟郎，三木博史，持丸章治，岩淵常太郎，竹田喜平 衛，加々見節男，大山正 : 発生土の利用率を高めた流動 化処理土の充填性に関する大型実物大実験の報告, 第 29 回土質工学研究発表会講演集, pp.2207-2210, 1994.

9) 流動化処理工法研究機構ホームページ : 施工実績につい て, http://www.lss-kiko.jp/bb/jisseki.htm.

10) Tatsuoka, F., Uchida, K., Imai, K., Ouchi, T. and Kohata, Y. : Properties of cement-treated soils in Trans-Tokyo Bay Highway project, Ground Improvement, Vol.1, pp.37-57, Thomas Telford, 1997

11）龍岡文夫 : 土質試験の課題と試験結果の評価一東京湾横 断道路計画における土質工学の諸問題と室内土質試験一, 昭和 61 年度最近の土質・基礎に関する講習会講演資料, 土質工学会, pp.55-103, 1976.

12）中村敦，青木一二三，村田修，木幡行宏，矢崎澄雄 : 掘 削発生土を利用した流動化処理土の配合試験，第 33 回 地盤工学研究発表会講演集, pp.2289-2290, 1998.
13）奥原祐治, 中村敦, 井上好一, 木幡行宏, 村田修, 矢崎 澄雄 : 流動化処理土の非排水三軸せ几断特性, 土木学会 第 53 回年次学術講演会講演概要集, 3-B, pp.626-627, 1998.

14）市原道三，木幡行宏，村田修 : 調整泥水式流動化処理土 の諸特性に及ぼす細粒分含有率の影響，土木学会第 54 回年次学術講演会講演概要集, 3-B, pp.384-385, 1999.

15）村田修，木幡行宏，神田政幸，棚村史郎，市原道三 : 流 動化処理土の非排水繰返し三軸特性，土木学会第 55 回 年次学術講演会講演概要集, 3-B, pp.556-557, 2000.

16) Goto, S., Tatsuoka, F., Shibuya, S., Kim, Y-S and Sato, T. : A simple gauge for local small strain measurements in the laboratory, Soil and Foundations, Vol.31, No.1, pp.169180, 1991.

17）木幡行宏, 前川晴義, 矢島寿一, 村本勝巳, 馬場崎亮一 : セメント系安定処理土の強度・変形特性について, セメ ント系安定処理土に関するシンポジウム発表論文集, 地 盤工学会, pp.1-19, 1996.

18）助川禎 : 泥水シールド発生土によるトンネルインバート 材の開発，土木学会論文集，No.504/IV-25，pp.107-116, 1994.

19）木村勝, 野島邦夫, 木幡行宏, 村田修, 梅原俊夫 : 高強 度流動化処理土の非排水三軸せん断特性，土木学会第 54 回年次学術講演会講演概要集, 3-B, pp.386-387, 1999.

20) 木幡行宏, 村田修, 梅原俊夫 : 高強度流動化処理土の繰 返し載荷による変形特性, 土木学会第 54 回年次学術講 演会講演概要集，3-B，pp.382-383, 1999.

21）久野悟朗，関口昌男：繊維質材料を混合した流動化処理 土の変形および支持力特性, 第 55 回土木学会年次学術 講演会講演集，pp.554-555，2000.

22) 木幡行宏, 藤川拓, 市原道三, 神田政幸, 村田修 : 繊維 混合流動化処理土の強度特性について，第 36 回地盤工 学研究発表会講演集, pp.635-636, 2001.

23）藤川拓，木幡行宏，市原道三，神田政幸，村田修：一軸圧 縮試験による繊維混合流動化処理土の強度・変形特性, 第 37 回地盤工学研究発表会講演集, pp.651-652, 2002.

24）木幡行宏, 對馬広紀, 藤川拓 : 長期養生した繊維材混合 流動化処理土の強度 - 変形特性, 地盤工学会北海道支部 技術報告集，第 43 号, pp.217-224, 2003.

25）木幡行宏, 蒋関魯, 龍岡文夫, 緒方紀夫 : セメント改良 砂質土の変形・強度特性に及ぼす養生日数の影響, セ メント系安定処理土に関するシンポジウム発表論文集, pp.137-142, 1996.

(2006. 7. 6 受付)

A Liquefied Stabilized Soil (LSS) was developed for an effective utilization of soil produced at a construction site in which a back filling soil for under ground structure cannot be compacted adequately. It is basic conception that an effect of cementation is expected by slurry soil, which have moderate flowability and no compaction, mixed with appropriate amout of cement. Recently, a recycling becomes the big stream of the times at the social level, LSS is using extensively in an urban area. In this paper, an experience of construction and trend of LSS is reviewed. The mechanical properties are discussed about LSS with low strength used as a back filling soil and LSS with high strength used in invert part of shield tunnel. The mechanical properties are discussed about LSS mixed with fiber reinforced material to increase the aseismatic performance. Finally, issues in the future of LSS are described. 